\title{
MOŽNOSTI POUŽITÍ ANALYTICKÝCH METOD V LOGISTICKÉ ANALÝZE REGIONU
}

\author{
Josef Botlík
}

\section{Klíčová slova:}

Logistika, logistický systém, sít’ová analýza, analytické metody, metody výzkumu, systémová analýza, incidenční matice, Petriho sítě

\section{Key words:}

Logistics, logistical system, network analysis, analytical methods, research methods, systems analysis, incidence matrix, Petri's networks

\begin{abstract}
Abstrakt
Článek se zabývá popisem analytických metod vhodných pro analýzu logistických systémů. Popis je zaměřen na širokou škálu, počínaje obecným popisem analytických metod, postupně upřesňuje metody vhodné pro logistiku a v závěru nastiňuje nové metody analýzy vhodné právě pro logistické systémy. Dále upřesňuje základní koncepty výzkumu, obecný popis přístupu k výzkumu, popis metod výzkumu a jejich aplikací, popis metodologie výzkumu se zaměřením na logistiku a z toho plynoucí popis metod využívaných $\mathrm{v}$ logistice.

Cílem je na základě sumarizace obecných metod následné nastínění souvislosti mezi řešením vybraných logistických problémů a speciálními maticovými operacemi aplikovanými na aparát Petriho sítí.
\end{abstract}

\begin{abstract}
The article deals with the description of analytical methods suitable for analysis of logistical systems. The description is focused on a wide range, starting with a general description of analytical methods, gradually specifying methods suitable for logistics and finally outlines new methods of analysis fit for logistical systems. Below the article specifies the basic concepts of research, the general description of the approach to research, the description of research methods and their applications, the description of research methodology focusing on logistics and the resulting description of the methods used in logistics. The aim is to summarize the general outline of the methods follow the link between the solutions of exclude logistical problems and special matrix operations applied to the apparatus of Petri's networks.
\end{abstract}

\section{Úvod}

Práce vychází z poznatků výzkumu prováděného v projektech CZ.1.07/2.3.00/09.0197, SGS/24/2010 a SGS/23/2010 v rámci řešení vlivu logistické infrastruktury na rozvoj regionu, nosnou částí bylo hledání obecně využitelného nástroje pro zachycení změn ve stavových veličinách v logistice, což jinými slovy znamená, nalezení snadno aplikovatelného nástroje umožňujícího analyzovat dynamické vlastnosti logistických systémů.

Jedná se tedy o řešení problematiky ve třech rovinách:

- v rovině prozkoumání vazeb regionální logistiky (regionálních trhů, regionální logistiky i regionálních vazeb na nadregionální celky),

- následně v rovině tvorby analytických nástrojů,

- aplikaci těchto nástrojů při zkoumání vlivu logistické infrastruktury na region. 
Dopady integračních procesů v Evropě na regionální logistiku, vlivy globalizace, dopady krize apod. znamenají pro regionální trhy změny v př́stupech k řešení vybraných logistických problémů.

Jedná se především o změnu př́istupu k analýze analýzu v oblastech ${ }^{1}$ :

- výběru zdrojů,

- zabezpečení dostupnosti zdrojů,

- zabezpečení náhradních zdrojů.

V návaznosti na tyto okruhy se dále jedná o řešení minimalizačních, maximalizačních a optimalizačních úloh, zejména z pohledů nákladů indukovaných změnou logistických struktur.

Při hledání analytických nástrojů je nutné se zaměřit na:

- jednotkové a násobné vzdálenosti a dostupnosti v logistických systémech,

- časové závislosti a jejich optimalizaci.

V praxi se jedná o řešení logistických systémů na základě klasické teorie systémů. Regionální systémy lze chápat jako podsystémy národních, či nadnárodních systémů.

Prvním krokem je definice analyzovaného systému, nalezení jeho hranic, definování podstatných vazeb na okolí, definování prvků a vazeb v systémech a stanovení hraničních prvků a vazeb mezi jednotlivými podsystémy.

Tyto vazby jsou východiskem pro možnou strukturální analýzu systémů, jinými slovy, pro analýzu rozložení logistických zdrojů a toků.

Stanovíme - li následně hodnoty atributů logistických prvků (například prvek „silnice“, atribut „kategorie“, hodnota atributu „rychlostní“), získáme na základě těchto hodnot stavy prvků (jako hodnoty atributů v čase) a tím i stavy systémů jako „časový snímek“ hodnot atributů systému v konkrétním okamžiku. Nalezneme potom dvě roviny analýzy logistických systémů, analýzu strukturální a analýzu ve stavovém prostoru (zpravidla dynamickém).

$\mathrm{Z}$ pohledu volby analytických metod jde především o analýzu řešení úloh týkajících se dopravních toků, toků zboží, rozložení zdrojů a míst spotřeby, úlohy o dostupnosti apod.

Analýzu problémů souvisejících s výše uvedenými okruhy lze přesunout částečně do roviny strukturální analýzy. Takováto analýza nám však neumožní zohlednění dynamických vlastností systémů. Nástrojem pro zohlednění stavových veličin ve struktuře systému jsou Petriho sítě, pomocí kterých můžeme do analýzy pomocí sítového grafu vnést pojem stavu definováním přechodových parametrů mezi jevy.

\section{Obecná metodologie, metody analýzy se zaměřením na logistiku}

Metoda, jako promyšlený, soustavný a cílevědomý přístup k řešení a postup při řešení problému, zahrnuje systém pravidel, která určují navazující možné systémy operací směřující od určitých výchozích podmínek k určitému cíli. ${ }^{2}$

Každá metoda má obecný cíl, tj. poznání skutečnosti a její změna k lepšímu. Ve významnějších případech se osvědčuje kombinace dvou nebo více metod. K nejdůležitějším předpokladům úspěchu v každé činnosti, patří správné zvolení metody, které vychází především ze správné znalosti metod.

Použití nevhodné metody vede ke zkreslení výsledků či ke špatné interpretaci.

\footnotetext{
${ }^{1}$ Jedná se pochopitelně pouze o dílčí výčet, účelově volený pro objasnění metodiky.

${ }^{2} \mathrm{Na}$ základě [3], [6], [14].
} 
Základní klasifikace metod je v podstatě shrnuta v literatuře [2], [3], [4], [6], proto uvedeme pouze zevrubné členění a principy.

Rozdíl je dán především formou možného popisu reality (např. metody popisu, sběru a analýzy dat). Jeden pól tvoří intuitivní, smyslový, neměřitelný (nebo obtížně měřitelný a klasifikovatelný) popis reality (empirický přistup), druhý pól tvoří exaktní, klasifikovatelný a škálovatelný př́ístup.

Základní klasifikace na metody empirické a exaktní je standardně doplňována o metody aplikovatelné v určitém odvětví. Více-méně se však tyto další metody vyčleňují z výše uvedených.

Např́iklad v [13], [15] je uvedeno, že mezi základní metody uplatňované v logistice patří:

- empirické metody,

- exaktní metody,

- specifické metody,

- metody tvůrčího myšlení,

- matematicko - statistické metody.

\section{Empirické metody}

Vycházejí ze zkušenosti a smyslů člověka, v některých případech doplněných o informace získané prostřednictvím technických prostředků (lupa, brýle, zesilovač apod.). Základní členění empirických metod lze shrnout podle [7], [13], [15] následovně:

- analogie,

- pozorování,

- dotazníky,

- testy,

- experiment,

- reflexe,

- měření.

\section{Exaktní metody}

Exaktní metody vycházejí z poznatků a aparátu exaktních věd. Exaktní znamená v moderním použití přesný, určený náročným měřením a podobně. Slovo se používá v běžné řeči jako synonymum pro přsnost ${ }^{3}$.

Exaktní věda je věda založená na přesných výpočtech, co nejpřesnějších měřeních a přísně testovaných hypotézách, takže dovoluje kvantitativní předpovědi. Mezi exaktní neboli teoretické metody patř́i:

- analýza a syntéza,

- indukce a dedukce,

- abstrakce,

- porovnávání a analogie.

Analytické a syntetické metody vycházejí z rozkladu celku na části a následné kompozice.

Analýza umožní definovat prvky, vlastnosti a vztahy. Důraz se klade na souvislosti. Jako nejrozšířenější metoda se objevuje ve velkém počtu forem: ${ }^{4}$

\footnotetext{
${ }^{3}$ Obecná definice - mimo seznam literatury. Viz Wikipedie nebo slovník cizích slov, př. http://slovnik-cizichslov.abz.cz/web.php/slovo/exaktni, , http://www.slovnik-cizich-slov.net/exaktni/. [Online 2010]

${ }^{4}$ Viz např. literatura [13].
} 
- klasifikační analýza - tř́ídění jevů na části (třídění jevů do skupin podle výrazných znaků - stroje, suroviny, materiály, pracovníci podle profesí, kvalifikace, věku),

- funkční analýza - uvádí vztahy do matematické závislosti (vztah jevů prostřednictvím matematické závislost, při níž jedna nebo několik nezávisle proměnných ovlivňuje změny jedné nebo několika závisle proměnných. Vyjádření rovnicí $\mathrm{y}=\mathrm{f}(\mathrm{x}))$,

- kauzální (př́ćčinná) analýza - se zaměřuje na prríčiny jevů a hledá vazby mezi nimi (napomáhá zjišt'ovat příčiny, které mají vliv na lepší nebo horší výsledky, na kvalitu, celkovou úroveň apod.) Základní formy příčinných souvislostí:

- jeden jev je příčinou druhého (př́ijem do skladu - výdej ze skladu) nebo se oba dva vzájemně podmiňují (kvalita a cena, zákazník a výrobce),

- dva nebo více jevů jsou následkem třetího (kvalitnější infrastruktura působí na rychlejší a levnější přepravu),

- jeden jev je následkem několika jiných (náklady na přepravu závisí na vzdálenosti, použité technologii, kvalitě infrastruktury apod),

- dva jevy souvisí pouze zdánlivě (vysoká pracnost a cena, velký objem zpracovávaného materiálu a kvalita),

- srovnávací analýza - vychází z analogie - dochází ke srovnání s obdobnými subjekty,

- hodnotová analýza - hledá lepší řešení funkce a objektu současně s lepším vztahem výnosů a nákladů,

- globální analýza - uvádí hlavní vztahy mezi jevy.

Pro logistiku je systémový přístup charakteristický [5]. Pracujeme přímo s logistickými systémy, podsystémy, prvky či vazbami. Analyzujeme toky, kapacity, časové průběhy apod. Je zřejmé, že v této rovině přejímá logistika aparát teorie systémů, resp. systémové a operační analýzy. V rámci klasifikační analýzy stanovujeme např. třídy silnic, priority dopravních koridorů, významnost logistických center, ale taky druhy dopravy a přepravy, druhy zásilek apod.

V rámci funkční analýzy vyjadřujeme v logistice např. přepravní kapacity (pojem hrubotuno kilometr - počítaná veličina přepravního výkonu apod.).

V rámci kauzální analýzy posuzujeme vhodnost a využitelnost umístění dopravních toků, jejich vliv na infrastrukturu či opačně apod.

Syntéza - (skládání - obecné označení pro proces spojování dvou nebo více částí do jednoho celku) znamená souhrnné poznání či vyzvednutí podstatných rysů, příčin a souvislostí.

Syntéza, jako jeden z nástrojů systémové analýzy, patří rovněž mezi základní logistické analytické nástroje. S ohledem na principy kompozice a dekompozice v logistických systémech, lze pomocí syntézy (a často ve spolupráci s metodami indukce) analyzovat logistické systémy na různých rozlišovacích úrovních a pracovat tak s páteřními tahy, multimodální dopravou apod.

Indukce - umožňuje př̀jít od zvláštního, jedinečného k obecnému, vychází ze znalosti všech možných případů. Používá se neúplná analýza, z celkového počtu vybíráme určité množství (vzorky).

Dedukce - úzce souvisí s indukcí (opačný postup - od obecného k jedinečnému).

Abstrakce - souvisí s konkretizací. Odhlédnutí od nepodstatných stránek, vlastností vztahů předmětů, pozornost se věnuje jen těm podstatným rysům. 


\section{Specifické metody}

Tyto metody, jak napovídá název, jsou specifické pro vybrané oblasti analýz. Bývají charakteristické např. scénáři, tvorbou stromových schémat a možnostmi tzv. rozhodování za rizika resp. nejistoty. ${ }^{5}$

\section{Další metody}

Mezi další metody analýzy patří např. metody tvưrčího myšlení. Základní dvě používají metody brainstormingu resp. brainwritingu. Princip vychází z pravidel, kdy se na všechny nápady nahlíží pozitivně, převládá kvantitativní složka, rovnost v náhledu na nápady apod., tyto metody jsou založeny na tvořivosti a na tvưrčím myšlení.

Další metody vycházejí z aparátu jiných vědních disciplín. Jedná se např. o statistické metody, matematické metody, metody operační analýzy apod. V rámci těchto metod dochází k prolínání a možné kombinaci s klasickými exaktními metodami, především analytickými a syntetickými.

\section{Metody používané v logistice}

Na závěr této kapitoly uvedu souhrn (podotýkám, že logicky neúplný) možných metod využitelných v logistice. Konkrétní nástroje a metody jsou podrobně popsány v [2].

\section{Metody teorie zásob}

$\mathrm{V}$ logistice patří systémy řízení zásob mezi jedny z prioritních. Existují různé formy a metody řízení zásob, jejich optimalizace, časové analýzy apod. Mezi základní systémy patří např̀. qsystém řízení zásob, p-systém řízení zásob, systém dvou zásobníků ap.

Při analýze, jak už bylo dřive uvedeno, používáme modelování a simulace. Modely řízení zásob mohou být chápány jako statické či dynamické, s ohledem na to, provádíme-li časovou analýzu nebo strukturální analýzu. Můžeme potom definovat a analyzovat statické modely teorie zásob, statický model s absolutně determinovaným pohybem zásob, statický model s pravděpodobnostně determinovaným pohybem zásob apod. V rámci zachycení stavů v čase potom využíváme dynamické modely teorie zásob, dynamický model s absolutně determinovaným pohybem zásob, produkční model, dynamické víceproduktové modely, modely s cenovou degresí nebo modely optimalizace pojistné zásoby.

\section{Metody teorie front}

Logistické systémy jsou charakteristické pohybem v čase a rozsáhlostí (nejen prostorovou, ale i co do počtu prvků a vazeb). Jako takové jsou náchylné k časové i prostorové kumulaci a shlukování. Tyto jevy můžeme popsat jako samostatné systémy, např. jednoduchý systém hromadné obsluhy s neomezenou frontou a s omezenou frontou, vícekanálový systém hromadné obsluhy s neomezenou frontou a s omezenou frontou, vícefázový systém hromadné obsluhy. Pro analýzu potom používáme napřr. metody optimalizace nákladů v systémech hromadné obsluhy.

\section{Metody sít'ové analýzy}

Na základě povahy logistických systémů, často reprezentovaných prostřednictvím sítí prvků a vazeb (křižovatky - silnice, sklady - toky zboží, nádraží - železnice apod.) můžeme přímo aplikovat metody sít’ové analýzy. Nejčastěji se analyzuje optimální spojení v síti, nejkratší cesta sítí, maximální tok sítí, trvání činností, vyhledání kritické cesty, analýza zdrojů, nákladová analýza apod.

\footnotetext{
${ }^{5}$ Tento výčet není úplný, další metody např. v [13].
} 


\section{Metody vícekriteriálního rozhodování}

Jako standardní věda, používá logistika i aparát matematických metod. Významně jsou při analýze zastoupeny metody vícekriteriálního hodnocení variant, metoda dvojkového hodnocení, metoda bodovací, modifikovaná metoda bodovací, metoda relativního hodnocení, metoda váženého součtu apod.

Z výše uvedeného výčtu je zřejmé, že aparát použitelný pro analýzu logistických dat a procesů je poměrně obsáhlý. Mezi nejpoužívanější matematicko-statistické metody a metody operační analýzy uplatňované v logistických procesech patří:

- modely zásob a rrízení skladů,

- modely hromadné obsluhy,

- metody teorie grafü,

- metody simulačního programování,

- metody matematického (analytického) modelování,

- metody matematicko-ekonomické optimalizace.

\section{Využití analytických nástrojů v regionálních logistických systémech}

Jak bylo uvedeno vúvodu, je výhodné analyzovat logistické systémy pomocí analýzy strukturální a analýzy ve stavovém prostoru.

Půjde především o analýzu a řešení úloh týkajících se dopravních toků, toků zboží, rozložení zdrojů a míst spotřeby, úlohy o dostupnosti apod.

$\mathrm{Z}$ důvodů zachycení dynamických procesů za současného dodržení jednoduchosti a účinnosti strukturální analýzy bude kritériem pro volbu analytických metod maximální využitelnost metod statické analýzy a snadná aplikovatelnost dynamických prvků do těchto nástrojů.

Z pohledu logistických procesů a volby analytických metod je možným nástrojem pro zohlednění stavových veličin ve struktuře systému aparát Petriho sítí, pomocí kterého můžeme do analýzy pomocí sít'ového grafu vnést pojem stavu definováním přechodových parametrů mezi jevy.

Celá úvaha vychází z následujících hypotéz:

1. logistické systémy lze popsat pomocí teorie systemů,

2. existují logistické systémy, které lze popsat aparátem sít'ových grafů,

3. pro analýzu těchto systémů je vhodný aparát precedenčních matic,

4. dynamické jevy logistických systémů lze zachytit pomocí bipartitních grafů,

5. precedenční matice bipartitních grafư mají v určitých systémech stejné chování jako precedenční matice sít'ových grafü.

\section{Analýza logistických procesů}

Podle různých základních definic je logistika rozmístění zdrojů v prostoru a čase, logistika je strategické řízení celého dodavatelského řetězce, je věda o řízení přepravy hmot. Technicky se logistika realizuje v systému jako účelově definovaná množina prvků a množina vazeb mezi nimi.

V první fázi je potřebné zjistit, zda lze logistické procesy popsat takovými systémovými nástroji, které umožní použití Petriho sítí. Vyjdeme-li opět z obecných logistických definicí, můžeme určit, že:

1. Logistika je tvořena technickými a organizačními opatřeními, tj. plánováním a optimalizováním procesů, jakož i jejich zavedením, udržením a ukončením. V systémech 
se transformují na materiály (látky, zboží) a biologické objekty (živé bytosti) $\mathrm{s}$ informacemi z počátečního do konečného stavu. Mění se jedna ze systémových veličin (místo, množství, druh a čas).

- Vidíme, že se jedná o změny ve stavech systému a o změnu systémových veličin. Jsouli měněnými veličinami místo, množství nebo čas, můžeme aplikovat metody sít'ové analýzy, ty jsou dále vhodné jako výchozí krok k analýze pomocí Petriho sítí.

2. Vlastnosti a chování logistických systémů charakterizované četnými vzájemnými vazbami je možno podchytit exaktně jen tehdy, sledujeme-li komplexně jak statické, tak dynamické projevy těchto systémů (o logistický systém se jedná, jestliže alespoň dva prvky systému jsou prvky logistickými a jsou uspořádány tak, že mohou převzít úkoly plánování, řízení a kontroly v systému.).

- V tomto případě je vhodnost použití Petriho sítí více než vhodná, protože rozšiřuje klasický aparát sít'ové analýzy o přechodové jevy, čímž umožňuje komplexně zahrnout jak statické, tak částečně i dynamické projevy.

3. Logistický systém se realizuje v logistických řetězcích. Řetězec je účelné uspořádání množiny technických prostředků pro uskutečňování logistických cílů. V systému jde o přemíst'ování věcí (osob) a přemíst'ování informací (nosičů informací, signálů apod.). Za články logistického řetězce považujeme závody, dílny, linky, sklady, komunikace, železnice, přístavy, letiště, prodejny velkoobchodu a maloobchodu apod.

- Je vidět přímá návaznost na metodologii neparametrických sítí a je zřejmá vazba na sít'ovou analýzu. Současně není definováno, jak se jednotlivé části logistického řetězce promítnou do popisu systému, což nám umožňuje použít popis pomocí precedenčních matic (matic zachycujících předchůdnosti jevů).

4. Při logistické transformaci dochází ke změně jedné ze základních systémových veličin tj. času, místa, množství nebo druhu operandů působením operátorů, aniž by se měnily nežádoucím způsobem látkové vlastnosti objektu.

- Tím je jednoznačně daná možnost použití Petriho sítí při analýze, protože analýza času a místa nebude mít za následek změnu vlastností objektu.

Systém je účelově definovaná množina prvků (elementů) a množiny vazeb (relací) mezi nimi, které spolu určují vlastnosti chování a funkce systému jako celku. Prvek systému je taková část systému, která tvoří na dané rozlišovací úrovni dále nedělitelný celek, jehož strukturu nemůžeme nebo nechceme dále rozlišit. Prvky jsou nositeli vlastností systému. Stav systému je množina podmínek, resp. vlastností, které lze v systému v daném časovém okamžiku rozpoznat a jež spolu se znalostí vstupů systému postačující informací pro určení výstupu systému.

Petriho sítě umožňují zachytit změny stavu systému velmi jednoduše jako změny značení (token) v systému.

Na základě výše uvedeného je možné provést posouzení vybraných metod z oblasti neparametrických sítí pro modelování v Petriho sítích, srovnání těchto metod a posouzení vhodnosti či nevhodnosti tohoto aparátu pro analýzu logistických sítí. V praxi se jedná o rozšíření maticového aparátu Petriho sítí, nalezení analogií mezi maticovými operacemi v sít'ových grafech a v Petriho sítích a zkoumání využitelnosti při analýze neparametrických sítí.

Vzhledem k obecné charakteristice těchto sítí můžeme při jejich analýze použít standardní metody sít’ové analýzy. 


\section{Sít'ová analýza}

Část problematiky týkající se analýzy logistických systémů a neparametrických sítí je možné zúžit do strukturální analýzy a analýzy tokủ. V systému, který je popsaný orientovaným grafem, můžeme relační vazby popsat jako precedence (předchůdnosti) a sukcedence (následnosti) v systému. Precedence i sukcedence můžeme následně popsat pomocí matic. Označíme - li postupně hrany jako 1-rozměrné prvky a uzly jako 0-rozměrné, můžeme definovat předchůdnosti uzel-uzel (matice $\mathrm{P}^{00}$ ), hrana-hrana $\left(\mathrm{P}^{11}\right)$, uzel-hrana $\left(\mathrm{P}^{10}\right)$ a hrana uzel $\left(\mathrm{P}^{01}\right)$, kde indexy udávají příslušný rozměr na základě rozměru použitých prvků. Dále můžeme definovat tokovou matici $\left(\mathrm{E}^{10}\right)$. Matice sukcedenční můžeme definovat jako transponované matice precedenční. Maticový aparát umožňuje zejména:

1. Implementaci kontrolních mechanismů,

2. implementaci nástrojů pro výběr částí systémů,

3. implementaci nástrojů pro hledání vybraných cest v systému.

Základní operací pro analýzu je operace výběru pomocí výběrového vektoru (vektor obsahující v příslušném poli znak „,“, je li příslušný prvek systému vybrán). Výsledkem operace je množina vybraných vektorů (sloupců) precedenční matice.

Nejčastěji následně provádíme sjednocení těchto vektorů, výsledkem je vektor udávající předchůdné činnosti k činnostem popsaných výběrovým vektorem.

Sloučíme-li operaci výběru a sjednocení, můžeme tuto operaci pracovně nazývat násobení (někde též kompozice) matice vektorem. Výsledkem je vektor. Budeme-li postupně násobit precedenční matici jednotlivými vektory téže matice, bude výsledkem množina vektorů udávajících druhé precedence. Tuto operaci můžeme chápat jako „násobení“ matice a množinu výsledných vektorů můžeme označit jako precedenční matici na druhou.

Protože platí jisté matematické vztahy, dostáváme aparát, který je nejenom vhodný k modelování, ale slouží současně jako mechanismus kontroly.

Závažným problémem sít’ových grafů je nemožnost rozlišení dynamických jevů, například přidělování či odebírání zdrojů. Klasické grafy nerozliší tyto jevy od jiných aktivit v systému. Pokud přepíšeme systém do podoby incidenční matice, nelze rozeznat rozdílnosti jevů.

Obrázek 1- graf systému a incidenční matice

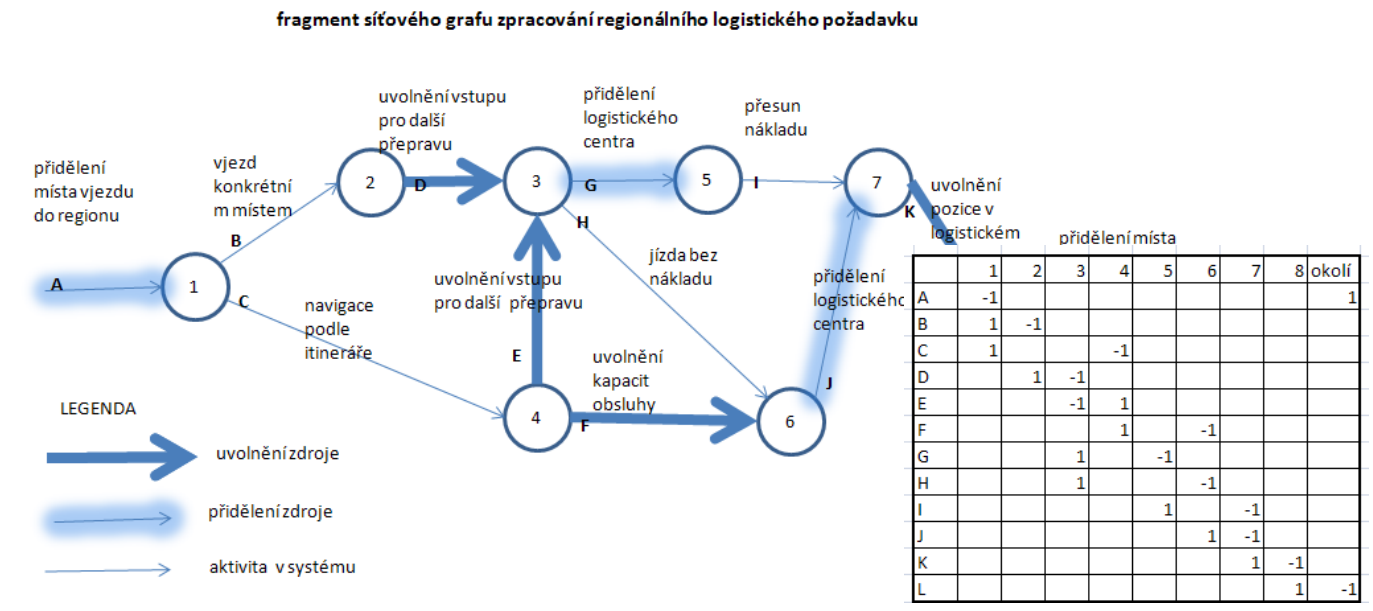

Zdroj: Vlastní 
Tento grafický a maticový zápis nic neříká o možnostech přechodech jednotlivých stavů v systému.

\section{Petriho sítě}

Petriho sítě jsou bipartitní grafy popsané pomocí dvou disjunktních množin vrcholů a hran mezi nimi.

\section{C/E Petriho sítě (Condition/Event PN)}

C/E Petriho sít je zadána následujícími údaji na základě kterých může být graficky zobrazena:

- podmínkami (conditions) zobrazovanými kroužky,

- událostmi (events) zobrazovanými obdélníky (př́ípadně úsečkami),

- hranami vedoucími od podmínek k událostem,

- hranami vedoucími od událostí k podmínkám,

- tokeny (zobrazenými tečkami v kroužcích podmínek) indikujícími logický stav (pravdivost) podmínek, jejich počáteční rozložení v síti nazýváme počátečním stavem nebo počátečním značením (initial marking) sítě.

Podmínka $c$ je vstupní podmínkou (precondition) události $e$, jestliže od podmínky $c$ vede hrana k události $e$, podmínka $c$ je výstupní podmínkou (postcondition) události $e$, jestliže od události $e$ vede hrana podmínce $c$. Každá podmínka je vždy bud' splněna, nebo nesplněna, každá splněná podmínka je indikována tokenem, tj. tečkou uvnitř kroužku zobrazujícího podmínku.

Stav sítě je dán množinou podmínek, které jsou v daném okamžiku splněny.

Změny stavů C/E Petriho sítě probíhají podle následujících pravidel:

- ke změnám stavu sítě dochází uskutečňováním událostí,

- událost může nastat, jsou-li všechny její vstupní podmínky splněny a současně všechny její výstupní podmínky nesplněny,

- provedena může být pouze proveditelná událost, proveditelná událost může také zůstat neprovedena,

- po provedení proveditelné události jsou všechny její výstupní podmínky splněny a všechny její vstupní podmínky nesplněny.

Obrázek 2 - provedení přechodu
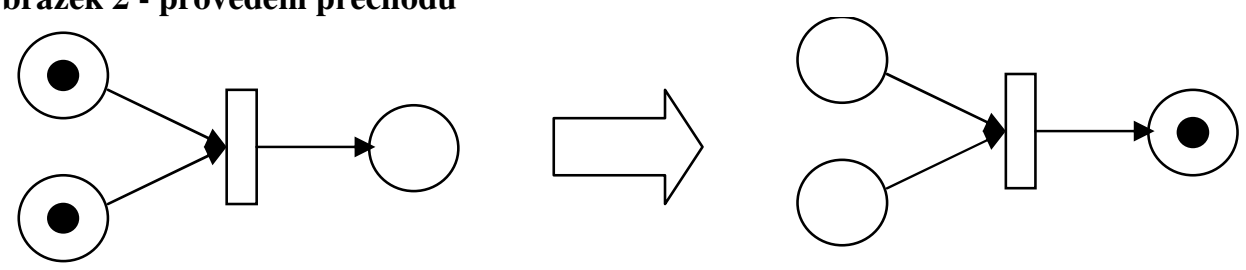

Zdroj: Vlastní

\section{P/T Petriho sítě (Place/Transitions PN)}

P/T Petriho sít je tvořena: obdobně jako C/E sít' s následujícími rozšířeními a odlišnostmi:

- kroužky označují „,místa“,

- obdélníky označují ,přechody“,

- je dána kapacita míst sítě,

- je dána váha hran sítě, 
Obrázek 3 - přechod P/T sítě

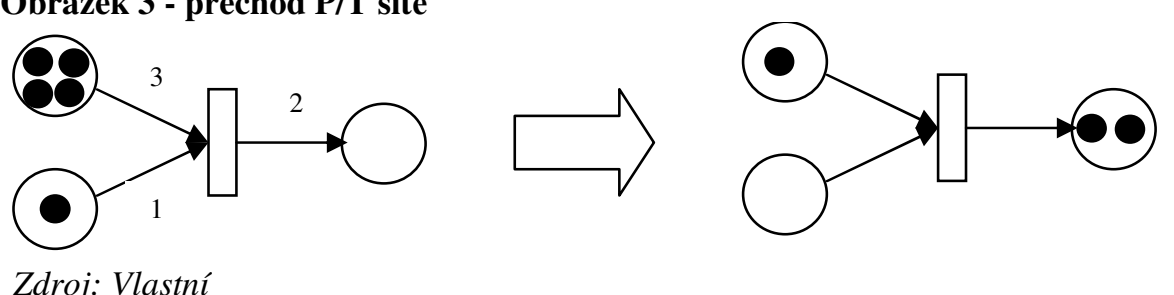

Pomocí Petriho sítí můžeme popsat dynamiku (stav) systému.

V rámci srovnávací analýzy lze dospět k závěru, že „místa“, „,přechody“, „kapacita míst“a „,váha hran“ jsou objekty charakteristické pro logistické systémy a je proto vhodné používat tento aparát pro analýzu logistických systémů.

Využití algebraických metod může potom být v Petriho sítích závislé na tom, máme-li dostupný př́slušný maticový aparát. V různých definicích (v různých zdrojích) můžeme vysledovat podobnost maticového aparátu Petriho sítí a sítových grafü.

Následující obrázek ukazuje analogii incidenční matice v Petriho síti s incidenční maticí v sít'ových grafech.

\section{Obrázek 4 - Petriho sít’ s incidenční maticí}

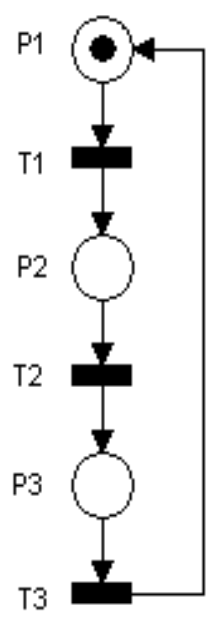

\begin{tabular}{|c|c|c|c|}
\hline & $\mathrm{T} 1$ & $\mathrm{~T} 2$ & $\mathrm{~T} 3$ \\
\hline P1 & -1 & 0 & 1 \\
\hline P2 & 1 & -1 & 0 \\
\hline P3 & 0 & 1 & -1 \\
\hline
\end{tabular}

Zdroj: Vlastní

Na základě tohoto popisu lze rozlišit, které jevy jsou událostmi a za jakých podmínek je lze zpracovat. V incidenční matici pak poznáme vazby mezi událostmi a podmínkami, rozeznáme vstupní a výstupní podmínky.

\section{Závěr}

Dosavadní průběh zkoumání precedenčních matic v Petriho sítích naznačuje existenci množiny základních matic Petriho sítí vhodných pro aplikaci algebraických metod v analogii se sít'ovým grafem. Označíme-li místa jako 2-rozměrné objekty (místo, značení), hrany jako 1-rozměrné a přechody jako 0-rozměrné, podstatně se nám rozšiřuje dostupný maticový 
aparát. Zejména výpočet mocnin příslušných matic umožňuje sledovat např̀. jednotkové posuny prováděných přechodů, jednotkové přesuny značení, nejdelší posloupnosti přechodů apod. Tím je vytvořený podklad pro sledování základních logistických jevů - přesunu zboží, přesunu požadavků, zjištění dostupnosti, zjištění podmínek dostupnosti apod.

Najdeme-li analogii mezi maticovým aparátem v Petriho sítích a klasických sít'ových grafech, dostaneme poměrně silný matematický aparát pro modelování logistických procesů.

Jak bylo uvedeno v úvodu, logistické jevy lze popsat pomocí systému, ze systému můžeme vyčlenit podsystém regionu. Na tento podsystém následně aplikujeme metody systémové analýzy. Dynamiku logistických procesů zachytíme pomocí PT (Place/Transitions) Petriho sítí. Pro strukturální analýzu prostorového rozložení (vazeb) mezi jevy v logistických systémech použijeme maticový zápis pomocí matic předchůdnosti (precedenčních matic).

Nalezením analogií mezi maticemi klasických systémů a maticemi Petriho sítí můžeme analyzovat a řídit jevy v logistických (tedy i regionálních logistických) systémech. Podrobněji je o dané problematice publikováno i např. v [16].

\section{Literatura:}

[1] BOTLÍK, J. Teze disertační práce. VŠB-TU Ostrava, 2007

[2] DRAHOVSKÝ, I., ŘEZNÍČEK .B. Logistika - procesy a jejich ř́zení. Praha: ComputerPress, 2003. ISBN: 80-7226-521-0

[3] FAJKUS, B. Filosofie a metodologie vědy. Vývoj, současnost a perspektivy. 1. Vyd. Praha: Academia, 2005,. 339 s. ISBN 80-200-1304-0

[4] GROS, I. Kvantitativní metody v manažerském rozhodování; Praha: Grada, 2003. ISBN: 80-247-0421-8

[5] PERNICA, P. Logistika (Supply Chain Management) pro 21. Století. Praha: Radix, 2004. ISBN 80-86031-59-4

[6] SIXTA, J., MAČAT, V. Logistika, teorie a praxe. Praha: ComputerPress, 2005. ISBN: 80-251-0573-3

[7] TULKA, J. Věda a vědecká metodologie. I. 4. vyd. Pardubice: Univerzita Pardubice, 2008. ISBN 978-80-7194-961-9

[8] WISNIEWSKY, M. Metody manažerského rozhodování. Praha; Grada, .1996. ISBN: 80-7169-089-9

Internetové zdroje:

[9] ̌REANKOVÁ, H. Postupy použivané při analýze dat. [Online 2009]

URL: http://badame.vse.cz/clanky/analyza-dat.php

[10] SURYNEK, A. Metody výzkumu a jejich aplikace - prezentace. [Online 2009] URL: http://kpsr.vse.cz/vyuka/materialy-k-predmetum/3ps423/

[11] ŠAFR, J. Kvantitativní metody výzkumu v praxi. [Online 2009] UK FHS, URL: kmvp.wz.cz/KMVP_3.ppt

[12] Metody výzkumu v sociální práci. [Online 2010] URL: http://www.zsf.jcu.cz/struktura/katedry/pore/czv/studijni_materialydokumenty/metody_vyzkumu_soc_prace/view

[13] Metody uplatňované v logistice oběhových procesů. [Online 2010] URL: http://myop.martinandco.eu/pdf/Metody\%20uplat\%C5\%88ovan\%C3\%A9\%20v\%20log istice $\% 20 \mathrm{ob} \% \mathrm{C} 4 \% 9 \mathrm{Bhov} \% \mathrm{C} 3 \% \mathrm{BDch} \% 20$ proces\%C5\%AF.pdf

[14] Moderní metody uplatňované v logistice. 2010. URL: www.haken.eu/studium/2.../Moderní\%20metody\%20v\%20logistice.doc 
[15] Stránky semináře předmětu Analytické metody výzkumu. [Online 2010] Fakulta sociálních věd UK, URL: http://metody.webz.cz

[16] Timed coloured Petri nets and their application to logistics [Online 2010], URL: http://wwwis.win.tue.nl/ wvdaalst/publications/p7.pdf

JEL klasifikace: L91, L99, O18, O22, R49, R58, C2, C51, C65

\section{Ing. Josef Botlík}

Odborný asistent Katedra informatiky

Obchodně podnikatelská fakulta V Karviné

Slezská univerzita v Opavě

Univerzitní náměstí 1934/3

73340 Karviná

botlik@opf.slu.cz 